\title{
UUDET OPPIMISYMPÄRISTÖT
}

\begin{abstract}
Tässä artikkelissa etsitään käsitteellistä jäsennystä oppimisympäristöjä koskevaan keskusteluun. Keskeisenä tarkastelukulmana on oppimisympäristön käsite, jota tarkastellaan sen osatekijöiden - fyysisen, sosiaalisen, didaktisen ja teknisen avulla. Avoin oppimisympäristö nähdään yläkäsitteenä, jonka alle erilaiset erityistapaukset, kuten kontekstuaaliset, virtuaaliset ja modernit oppimisympäristöt asettuvat.
\end{abstract}

\begin{abstract}
Samalla kun kätevä monimuoto-käsite on siirtymässä edeltäjänsä etäopetus-käsitteen seuraksi historian hämärään, on aikuiskoulutuksen retoriikkaan viime vuosina entistä enemmän pesiytynyt lukuisa määrä erilaista oppimisympäristöihin liittyvää uutta terminologiaa. Keskusteluissa vilisevät uudet termit virtuaalinen oppimisympäristö (Pantzar \& Väliharju 1996; Keegan 1996), avoin oppimisympäristö (Tella 1994; Manninen 1996; Pantzar \& Väliharju 1996; Kauppi 1995), avoin oppiminen (open learning; Rowntree 1992), digitaalinen oppimisympäristö (Tertsunen \& Viteli 1997), moderni oppimisympäristö (Lehtinen 1997, 23; Pantzar \& Väliharju 1996, 29) ja verkostopobjainen oppimisympäristö (Hakkarainen 1997). Kehitteillä on virtuaalikirjastoja oppimisympäristöiksi, virtuaalinen avoin yliopisto ja Kauppakorkeakouluun jopa virtuaaliprofessuuri. Usein termejä avoin, virtuaalinen ja moderni käytetään synonyymeina tai ainakin kuvaamaan samaa tutkimuskohdetta (esimerkiksi Pantzar \& Väliharju 1996).
\end{abstract}

Käytännössä em. termien kuvaamilla 'ympäristöillä’ on kuitenkin varsin vähän tekemistä keskenään. Virtuaalinen ja moderni ei välttämättä ole avoin, eikä avoimuus vaadi modernin teknologian käyttöä. Vaikuttaisi siltä, että 'oppimisympäristö' erilaisine määreineen on Suomessa tullut samaan käyttöön kuin aikoinaan käsite 'avoin oppiminen' anglosaksisissa maissa, jonka määritelmää eräässä 1970-luvulla ilmestyneessä Unescon raportissa kuvataan seuraavasti:

“[avoin oppiminen] on epämääräinen käsite, johon voidaan liittää, ja liitetään, monenlaisia merkityksiä... ja joka jää aina määrittelemättä. Mutta juhlakulkueen kärjessä kannettavan, kannattajia ja intoilijoita kokoavan banderollin iskusanana se toimii mainiosti” (sit. Rowntree 1992, 13).

Tässä artikkelissa etsitään käsitteellistä jäsennystä oppimisympäristöjä koskevaan keskusteluun. Keskeisenä tarkastelukulmana on oppimisympäristön käsite, jota tarkastellaan sen osatekijöiden (fyysinen, sosiaalinen, didaktinen, tekninen) avulla. Avoin oppimisympäristö nähdään tässä yläkäsitteenä, jonka alle erilaiset erityistapaukset (kontekstuaaliset, virtuaaliset, modernit jne. oppimisympäristöt) asettuvat. Oppimisympäristön avoimuutta tarkastellaan tiettyjen aikaan, paikkaan ja didaktisiin ratkaisuihin liittyvien aste-erojen suhteen. Lopuksi pohditaan uuden viestintäteknologian roolia ja merkitystä.

Artikkelissa käytetään tietoisesti kirjallisuudessa ja keskustelussa vakiintunutta termiä 'oppimisympäristö’, vaikka olisi parempi puhua 'opiskeluympäristöstä'. 


\section{Oppimisympäristö}

Oppimisympäristö määritellään tässä paikaksi, tilaksi, yhteisöksi tai toimintakäytännöksi, jonka tarkoitus on edistää oppimista. Määritelmä on tarkoituksella väljä ja epämääräinen, koska muuttuvia käytäntöjä ei ole helppo kuvata perinteisin termein. Vastaavantyyppinen määritelmä on Wilsonin (1996) esittämä:

"A learning environment is a place or community where people can draw upon resources to make sense out of things and construct meaningful solutions to problems" (Wilson 1996, 3)

Oppimisympäristöjä voidaan tarkastella ainakin kolmesta näkökulmasta; organisaatiokeskeinen näkökulma korostaa ympäristöä fyysisenä tilana (luokkahuone, [avoin] oppimiskeskus, opetustila jne.) tai koulutusohjelmana/toimintakäytäntönä (esim. HOPSit, PD-ohjelmat, 'oppiva organisaatio'), oppijakeskeinen näkökulma tarkastelee yksilö keskipisteenään oppijan arkipäivässä, opiskelussa ja työssä vastaantulevia oppimisresursseja ja -tiloja, ja teknologianäkökulma rakentelee oppimisympäristöt teknisten apuvälineiden varaan, ääritapauksissa tekniikan 'sisään' (esim. cd-rom, WWW-sivut, internetin keskusteluryhmät).

Oppimisympäristöllä siten viitataan usein joko fyysiseen (luokkahuone, oppimiskeskus) tai virtuaaliseen (esim. tietokonekokous, kolmiulotteinen virtuaalinen 'tila', multimediaympäristö jne.) tilaan. Valitettavan usein oppimisympäristöön liittyvät 'henkiset' määreet eli sosiaalinen ilmapiiri ja muoto sekä didaktinen lähestymistapa unohdetaan, vaikka niitä voidaan pitää juuri niinä tekijöinä jotka tekevät 'tilasta' tai 'paikasta' oppimisympäristön. Oppimisympäristöjen kehittelijöiden tulisi siten aina pohtia, mitä on hyvä ja laadukas oppiminen ja miten suunniteltu ympäristö sitä edistää.

\section{Oppimisympäristön ilmapiiritekijät}

Oppimisympäristöjen ilmapiiritekijöihin on alettu kiinnittää entistä enemmän huomiota aikuiskoulutuksen laajentumisen ja erityisesti humanistisen osallistujakeskeisen lähestymistavan myötä. Amerikkalaiseen tapaan ilmapiiritekijöiden (learning climate) merkitystä on korostanut erityisesti Malcolm Knowles osana andragogista suunnittelumallia (kts. Manninen \& al. 1988). Knowles on eritellyt sosiaalisen (esimerkiksi keskinäisen kunnioituksen, yhteistyön ja mielihyvän ilmapiiri) ja fyysisen (esimerkiksi pöytien ja tuolien asettelu, valaistus, mukavuus; jopa kurssipaikalle opastus ja parkkipaikkojen saatavuus) ympäristön merkitystä. Sosiaalisen ympäristön rakentaminen on viime vuosina laajennettu kattamaan myös etnisiä, valtasuhteisiin liittyviä ja gender-teemoja käsitteleviä pohdintoja (esim. Merriam 1993). Erilaisten telemaattisten välineiden opetussovellusten myötä voidaan puhua myös teknisestä ilmapiiristä, jonka alle voitaneen sijoittaa esim. välineiden helppokäyttöisyys, luotettavuus, edullisuus, nopeus ja ihmisläheisyys. Vastaavalla tavalla voidaan oppimisympäristön osatekijäksi nostaa didaktinen ilmapiiri, joka voi tarkoittaa esimerkiksi Jarvisin (1990) kuvaamaa itse- ja ulkoa-ohjautuvuuden toteutumista opiskeluprosessissa tai laajemminkin didaktista lähestymistapaa, jonka varaan opetus ja oppiminen on rakennettu (kts. esim. Kauppi 1989).

Didaktisten lähestymistapojen ja uusien oppimisympäristöjen suhteen käsittely olisi oman artikkelin aihe, eikä siihen ole sen vuoksi mahdollista mennä syvällisesti tässä yhteydessä. Oppimisen, opetuksen ja teknologian suhdetta koskevan tutkimustiedon vähäisyys ei ainakaan ole ongelma (kts. esim. Jonassen 1996, sivut 11245). Todettakoon kuitenkin, että yleinen tapa linkittää nykyisin muodissa oleva konstruktivistinen oppimiskäsitys automaattisesti moderneihin/virtuaalisiin/avoimiin oppimisympäristöihin on varsin yksinkertaistava näkökulma, joka hukkaa suuren osan sekä aikuisopetuksen/ oppimisen ja uusien oppimisympäristöjen mahdollisuuksista. Konstruktivismin suosion taustalla lienee ainakin osittain (helpon omaksuttavuuden ja sovellettavuuden sekä myyvän termin lisäksi) ko. oppimisnäkemyksen yhteensopivuus Internetin ja hypertekstien mahdollistaman informaatiotulvassa surffailun kanssa. 
Jos ja kun oppijan nähdään rakentavan todellisuuskuvansa aktiivisesti itse ja vuorovaikutuksessa muiden tietämättömien kanssa, antaa maailmanlaajuinen informaatioverkko (ei siis tietoverkko) keskustelumahdollisuuksineen siihen erinomaiset mahdollisuudet. Surffailuahan ei opettaja edes saa suunnitella etukäteen, mikäli konstruktivismin periaatteita tiukasti sovelletaan.

Erilaisia oppimisteorioita (kts. esim. Duffy \& Jonassen 1992; Inglis 1996; Lonka 1997) ja didaktisia lähestymistapoja (esim. Kontiainen \& Manninen 1997; Kauppi 1989; Tennant 1988) on kuitenkin olemassa runsaasti, ja monet poikkeavat toisistaan huomattavasti oppimis- ja opettamiskäsityksen sekä filosofisen taustansa suhteen. Esimerkiksi edellisen muotivillityksen eli engeströmiläisen kognitiivisen didaktiikan ja uuden konstruktivismin välillä on sukulaisuudesta huolimatta selkeitä todellisuuden luonteeseen liittyviä eroja, joita harva kuitenkaan tiedostaa. Erilaisiin oppimistilanteisiin ja -tarpeisiin myös soveltuvat erilaiset lähestymistavat, joten konstruktivismin ylikorostuminen saattaa johtaa myös oppimisympäristöjen yksipuolistumiseen. Polkupyöräilyä oppii parhaiten 'learning by doing' -periaatteella, auton moottorin toimintaperiaatteen engeströmiläiseen orientaatioperustaan pohjautuvalla kurssilla, sosiaalisiin rooleihin ja arvoihin liittyvää vapautumista radikaaliin humanismiin perustuvissa kommunikatiivista oppimista tukevissa tilanteissa, jotka voivat hyvin olla 'virtuaalisia' (kts. Manninen 1991, 1992).

\section{AVOIMET OPPIMISYMPÄRISTÖT}

'Uusien' eli aikaisemmasta poikkeavien koulutuskäytäntöjen yhteisnimittäjänä voidaan pitää avoimuutta ja joustavuutta; avoimuus näyttäytyy usein opiskelijakeskeisyytenä ja sitä kautta selkeiden opetussuunnitelmien puuttumisena (esim. yksilön elämäntilanteista ja tarpeista lähtevä koulutus, konstruktiivinen tiedon rakentaminen), prosessikeskeisyytenä (tärkeintä on opiskeluprosessi sinänsä, ei niinkään ensisijaisesti tavoitteet, jotka voivat myös muuttua ja täsmentyä), erilaisten monimuotoisten opetusmenetelmien soveltamisena perinteisen opettajajohtoisen luokkahuoneopetuksen sijasta, oppimisympäristön avoimuutena ja verkostoitumisena työelämään ja konkreettisiin (tai simuloituihin) reaalimaailman tilanteisiin (esim. työharjoittelun kautta), ja ennen kaikkea erilaisten opiskelijaa tukevien ohjauskäytäntöjen merkityksen lisääntymisenä. Ohjauksen lisääntyvästä merkityksestä huolimatta oppijan oma aktiivisuus ja itseohjautuvuus asetetaan ihanteeksi.

Useimpien määritelmien mukaan avoin oppimisympäristö on sellainen, jossa pyritään saamaan aikaan optimaalinen joustavuus ajan, paikan, menetelmien, toteutustapojen ja oppisisältöjen suhteen (esim. Lewis 1992; Rowntree 1992, 14; Pantzar \& Väliharju 1996, 2527). Aikuiskouluttajan rooli puolestaan muuttuu oppimisympäristön suunnittelijaksi, oppimisen ohjaajaksi, asiantuntijaksi ja tiimin jäseneksi. Perusperiaate on, että opiskelu muuttuu opiskelijakeskeiseksi perinteisen opettaja- tai oppilaitoskeskeisyyden sijasta. Usein pyritään myös luomaan linkki konkreettisen toiminnan ja opiskelun välille (esimerkiksi työharjoittelun tai simulaatioiden avulla).

Opiskeluympäristöjen avoimuutta ja joustavuutta voidaan arvioida ja kuvata sivun 271 kuvion jäsennyksen pohjalta (vrt. Manninen 1996, 23). Malli perustuu osittain Paulsenin (1992) esittämään etäopetusmalliin sekä Jarvis'in itseohjattua opiskelua kuvaavaan malliin (Jarvis 1990). Eri dimensioiden tarkoitus on kuvata jatkumoa, joka toteutuu todellisissa oppimis- ja opetustilanteissa eri asteisesti. Esimerkit ovat dimensioiden ääripäitä, jotka harvoin toteutuvat puhtaina ja ääritapauksina. Merkittävää mallin osalta on se, että oppimisympäristö voi olla hyvinkin avoin jonkin osatekijän suhteen, mutta samanaikaisesti suljettu muiden dimensioiden osalta (esim. ajan ja paikan osalta joustava ja vapaa, mutta oppisisällöt ennakkoon määriteltyjä ja kaikille samoja; vrt. esim. tietokoneavusteiset opetusohjelmat, itseopiskelupaketit).

On syytä huomata, että tietyt opiskelujärjestel- 


\begin{tabular}{|c|c|c|c|}
\hline & SULJET'TU & $<----->$ & AVOIN \\
\hline MOTIIVI & ulkoinen & $<----->$ & sisäsyntyinen \\
\hline OPISKELUPÄÄTÖS & $\begin{array}{l}\text { muiden painostuksen } \\
\text { tai pakon myötä }\end{array}$ & <------> & omaehtoinen \\
\hline OSALLISTUMISTAPA & $\begin{array}{l}\text { perinteinen kurssi- } \\
\text { muotoinen }\end{array}$ & <-----> & itseopiskelu \\
\hline TAVOITTEIDEN & & & \\
\hline MÄÄRITTELY & $\begin{array}{l}\text { kouluttaja, organisaatio, } \\
\text { yhteiskunta }\end{array}$ & $\mid<---->$ & itse \\
\hline AIKA & sovitut kokoontumiset & $<----->$ & $\begin{array}{l}\text { vapaus ajasta, opiskelu } \\
\text { omaan tahtiin milloin vain }\end{array}$ \\
\hline PAIKKA & $\begin{array}{l}\text { opiskelu sidottu tiettyyn } \\
\text { paikkaan }\end{array}$ & $<----->$ & $\begin{array}{l}\text { vapaus paikasta, } \\
\text { opiskelu missä vain }\end{array}$ \\
\hline OPPISISÄLLÖT & kaikille yhteiset & $<----->$ & yksilöllisesti räätälöidyt \\
\hline $\begin{array}{l}\text { OPISKELTAVAN } \\
\text { TIEDON LUONNE }\end{array}$ & $\begin{array}{l}\text { selkeästi rajatut ongelmat } \\
\text { ja vastaukset, oppiaine- } \\
\text { perustaisuus; } \\
\text { tiedon objektiivisuus }\end{array}$ & $<----->$ & $\begin{array}{l}\text { laajat, soveltamista ja } \\
\text { ongelmanratkaisua vaativat } \\
\text { kokonaisuudet; tiedon } \\
\text { relativistisuus }\end{array}$ \\
\hline KONTEKSTI & oppilaitos & $<----->$ & reaalitodellisuus \\
\hline $\begin{array}{l}\text { YHTEYS REAALI- } \\
\text { MAAILMAAN }\end{array}$ & puuttuu kokonaan & $<----->$ & $\begin{array}{l}\text { ongelmakeskeinen, oppimis- } \\
\text { projektipohjainen opiskelu }\end{array}$ \\
\hline SAAVUTETTAVUUS & $\begin{array}{l}\text { opiskelijat valitaan, } \\
\text { pääsykokeet }\end{array}$ & $<----->$ & avoin kaikille halukkaille \\
\hline TOTEUTUSTAPA & kurssipohjainen & $<----->$ & itseopiskelu \\
\hline OPISKELUTAHTI & ennaltamäärätty & $<----->$ & itse määrätty \\
\hline $\begin{array}{l}\text { VÄLINE/ } \\
\text { MENETELMÄT }\end{array}$ & $\begin{array}{l}\text { yksi tiedon välittämisen/ } \\
\text { omaksumisen kanava }\end{array}$ & $<----->$ & $\begin{array}{l}\text { useita vaihtoehtoisia tai } \\
\text { toisiaan täydentäviä välineitä }\end{array}$ \\
\hline $\begin{array}{l}\text { YHTEISTOIMINNAL- } \\
\text { LISUUS }\end{array}$ & $\begin{array}{l}\text { yksinopiskelua, ajattelu- } \\
\text { ja reflektioprosessit } \\
\text { tapahtuvat yksin }\end{array}$ & $<----->$ & $\begin{array}{l}\text { yhteistoiminnallilsta, vuoro- } \\
\text { vaikutukseen perustuvaa } \\
\text { oppimista }\end{array}$ \\
\hline ARVIOINTI & ulkopuolisen toimesta & $<----->$ & itsearviointi \\
\hline
\end{tabular}


mään liittyvät valinnat (esim. didaktisesti tehokas ryhmäpohjaisuus) rajaavat liikkumavaraa muissa kohdissa (esim. opiskelutahdin, ajan, oppisisältöjen ja paikan suhteen). Täysin avointa opiskeluympäristöä on siten käytännössä varsin vaikea toteuttaa, eikä se ole kaikissa tilanteissa didaktisesti järkevää (esim. ryhmäytymistä ja välitöntä vuorovaikutusta vaativat tilanteet ja prosessit). Paulsen (1992) puhuukin ilmiöstä nimeltä 'cooperative freedom', joka tarkoittaa yhteistoiminnallista mutta ajasta ja paikasta osittain vapaata oppimistilannetta, jossa yksilön vapaus kapenee mutta korvautuu vuorovaikutuksen hyvillä puolilla. Vastaavalla tavalla voidaan paikantaa esim. Mezirowin didaktisessa lähestymistavassa siirtyminen yksilöllisyyden ja itseohjautuvuuden korostamisesta keskinäiseen riippuvuuteen (interdependence), joka mahdollistaa toiminnallisesti ja didaktisesti hyvät oppimistulokset (kts. AhteenmäkiPelkonen 1994).

Teknologian ja telemaattisten etäopetusvälineiden osalta malli osoittaa, että ne muodostavat vain yhden avoimen oppimisympäristön osatekijän. Telemaattisen innostuksen vallassa olevien on siksi syytä muistaa, että virtuaaliset oppimisympäristöt eivät sellaisenaan takaa oppimisen avoimuutta ja kontekstuaalisuutta. Päinvastoin, vain yhteen välineeseen (esim. WWW-sivut) perustuva oppimisympäristö voi pahimmillaan olla - ajasta ja paikasta vapautumisesta huolimatta - hyvinkin suljettu muiden tekijöiden suhteen. Uusi teknologia kuitenkin mahdollistaa oikein käytettynä oppimisympäristöjen optimaalisen avoimuuden, ja ratkaisee myös monia käytännön didaktisia dilemmoja (esim. keskusteluryhmien mahdollistama yhteistoiminnallinen ryhmässä oppiminen ajasta ja paikasta riippumatta; kts. Paulsen 1992 ja Manninen 1992). Perinteisen opettajajohtoisen opetuksen siirto tietokoneavusteiseksi ei kuitenkaan ole sellainen innovaatio, jota voi pitää mitenkään järkevänä.

Seuraavassa tarkastellaan vielä syvemmin kahta avoimen oppimisympäristön erikoistapausta, jotka ovat muotoutumassa koulutuskäytännöiksi.

\section{KONTEKSTUAALISET OPPIMISYMPÄRISTÖT}

Kontekstuaalisen eli todelliseen toimintaympäristöön sijoittuvan oppimisympäristön käsitettä on vahvimmin tuonut esille Antti Kauppi (1993 ja 1995). Perusargumentti on oppimisen ja opiskelun siirtäminen pois suljetuista luokkahuoneista todellisiin ympäristöihin. Tällöin siirrytään pois opetussuunnitelma-ajattelusta (oppitunteihin jaettu, oppisisältöihin pohjautuva opettajajohtoinen toiminta) oppimisympäristöajatteluun, jossa oppimisen kohteena ei ole oppisisältö vaan reaalitodellisuus ja sieltä nousevat ongelmat. Opiskelija muuttuu aktiiviseksi kokeilijaksi ja tekijäksi, opettaja tukijaksi ja ohjaajaksi.

Esimerkiksi perheenäideille suunnattu matematiikan opiskelu on mielekkäämpää, jos se toteutetaan kaupassa arkisten ostosten yhteydessä (esimerkiksi alennusprosenttien laskeminen). Kontekstuaalisessa lähestymistavassa oppiainekeskeisyys korvataan ongelmakeskeisyydellä ja tentit soveltavilla, todellisiin ongelmatilanteisiin liittyvillä tehtävillä. Käytännön esimerkkinä ammatillisen koulutuksen alueella toteutetuista kontekstuaalisista oppimisympäristöistä voidaan pitää erilaisia harjoitusyrityksiä, joissa simuloidaan todellisten yritysten toimintaa (kts. Kauppi 1995).

\section{VIRTUAALISET OPPIMISYMPÄRISTÖT}

Erityisen paljon pinnalla ollut muotitermi on virtuaalinen (tai moderni) oppimisympäristö, jolla tarkoitetaan tässä telemaattisin välinein (sähköposti, tietokonekokoukset, www, videoneuvottelu, puhelin, audiografiikka, cd-rom, multimedia jne.) toteutettua, pääosin etäopetuksena toteutettavaa ympäristöä. Käytännön esimerkkinä on 'virtuaalinen luokkahuone', joka voi olla esimerkiksi tietokonekokouspohjainen 'ympäristö', joka mahdollistaa osanottajien vuorovaikutuksen ajasta ja paikasta riippumatta. Yksiulotteisina ja tekstipohjaisina tällaiset 'virtuaaliset luokkahuoneet' ovat olleet olemassa jo useita vuosia, mm. tieto-koneko- 
kousympäristöissä toteutettuina (kts. esimerkiksi Manninen 1992).

Virtuaali ei terminä ole kuitenkaan ongelmaton. Sivistyssanakirjan mukaan virtuaali(nen) tarkoittaa oletettua, periaatteessa mahdollista. Arkikielessä virtuaalisuus taas voidaan liittää esimerkiksi keinotodellisuuden piirteisiin. Virtuaalisen oppimisympäristön lisäksi puhutaan verkkopedagogiikasta ja virtuaaliopetuksesta (virtual education), joka voidaan ymmärtää hyvinkin eri tavoin. Virtuaaliopetusta ei esimerkiksi aina käsitetä ajasta ja paikasta riippumattomaksi. Muun muassa Keegan (1996) näkee virtuaaliopetuksen liittyvän siihen etäopetuksen alueeseen, mikä tapahtuu 'face-to-face' (esim. videoneuvotteluyhteys), ja luokittelee sen mukaan myös eroja etäopetuksen ja virtuaaliopetuksen välillä. Keeganin määritelmän mukaan etäopetus mahdollistaa kurssien tarjonnan ajasta ja paikasta riippumatta, kun taas virtuaaliopetus pakottaa oppilaat menemään johonkin erityiseen 'virtuaaliluokkaan', jossa esimerkiksi satelliittiyhteydet ovat mahdollisia. (Keegan 1996, 8-9.) Vastaavasti Helsingin Sanomien verkkoliite ('virtuaaliopetus yleistyy', lokakuu 1997) toteaa, että aidossa virtuaalikoulussa opiskelijat pystyvät suorittamaan opintonsa verkossa ajasta ja paikasta riippumatta, mutta artikkelissa viitataan kuitenkin verkkoluentoihin ja verkkopuhelimiin, jotka eivät vapauta opiskelijaa ajasta tai paikasta.

Keeganin käsitys virtuaaliopetuksesta on kapea, mutta virtuaaliopetus voidaan ymmärtää myös laajasti koskemaan kaikkea sellaista opiskelua, jossa hyödynnetään uusia teknologioita. Esimerkiksi www:iin sisälle rakennetussa virtuaalisessa oppimisympäristössä mahdollistuu sekä samanaikaisesti (synchronous) että eriaikaisesti (asynchronous) tapahtuva opiskelu. Verrattuna perinteisempiin etäopetuksen muotoihin www tarjoaa vuorovaikutuksen osalta paljon suuremman määrän vaihtoehtoja.

Interaktiivisen multimediateknologian kehitys mahdollistaa helpotuksia sekä yksilöllisessä että yhteistoiminnallisessa oppimisessa ja hämärtää rajoja etä- ja traditionaalisen opetuksen välil- lä. Näillä uusilla teknologioilla on mahdollista luoda uusia oppimisympäristöjä, kuten virtuaalisia yhteisöjä (virtual communities). Esimerkiksi tietokoneverkkojen (www) avulla oppilaat voivat osallistua globaaliseen luokkahuoneeseen ympäri maailmaa ja olla vuorovaikutuksessa keskenään; esimerkiksi informaatiota jakaen tai työskentelemällä yhdessä autenttisissa oppimistilanteissa. (McIsaac \& Gunawardena 1996, 403.)

\section{Virtuaalinen ja avoin kontekstuaalinen oppimisympäristö?}

Olisi hyvä pohtia, miten avoin, kontekstuaalinen ja virtuaalinen oppimisympäristö suhtautuvat käsitteellisesti ja käytännössä toisiinsa. Telematiikan hyödyntäminen opetuksessa ei suinkaan johda automaattisesti avoimeen tai kontekstuaaliseen oppimisympäristöön, vaan päinvastoin uuden teknologian avulla voi toteuttaa myös hyvinkin suljettuja ja reaalitodellisuudesta irrallaan olevia oppimisympäristöjä (kts. myös Kauppi 1995). Esimerkiksi wwwpohjainen opetus voi perustua hyvinkin tarkkaan ennalta määrätyille oppisisällöille, etenemispoluille ja ratkaisuille. Toisaalta moderni teknologia antaa periaatteessa entistä paremmat mahdollisuudet opetuksen ja opiskelun yksilölliseen eriyttämiseen. Näiden kolmen ympäristömallin suhdetta voisi kuvata kuviolla 2 (sivu 274).

Virtuaalinen eli telemaattisia välineitä byödyntävä 'oppimisympäristö' sijoittuu tähän kuvioon kolmantena ulottuvuutena (jota on kuitenkin vaikea kuvata kaksiulotteisessa mediassa), lähinnä teknisenä ratkaisuna, joka ei siis sellaisenaan takaa oppimisympäristön avoimuutta tai kontekstuaalisuutta. Esimerkiksi luokkahuoneopetuksen virtuaalisovellus voisi olla videoneuvotteluyhteys kahden luokkahuoneen tai luentosalin välillä.

Kontekstuaalisesta mutta suljetusta oppimisympäristöstä on vaikeampi keksiä 'puhdasta' esimerkkiä, koska todellisiin ympäristöihin siirryttäessä tapahtuu aina automaattisesti avautumista edellä kuvatun avoimen oppimisympäristön 


\section{MANNINEN\&PESONEN}

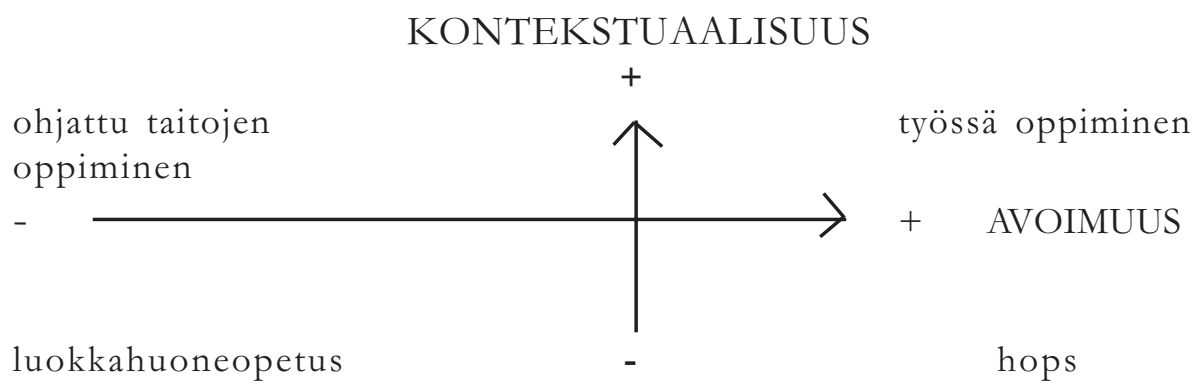

KONTEKSTUAALISUUS

ohjattu taitojen

oppiminen

mallin tiettyjen tekijöiden suhteen (konteksti ja yhteys reaalimaailmaan). Yllä olevaan kuvioon on merkitty ohjattu taitojen oppiminen, joka voi olla esimerkiksi ryhmässä tapahtuvaa ratsastuksen opiskelua (konteksti reaalitodellisuus, mutta oppisisältö kaikille sama). Hyvänä käytännön esimerkkinä kontekstuaalisesta, mutta varsin ei-avoimesta oppimisesta voisi pitää armeijan aseenkäsittelykoulutusta; oppiminen tapahtuu todellisissa tilanteissa, mutta oppisisältöjen, ajan, paikan, opiskelutahdin ja muiden mallissa kuvattujen ulottuvuuksien suhteen liikutaan selkeästi asteikon suljetussa päässä. Virtuaalisen version voisi periaatteessa kehittää uudella simulaattoritekniikalla, jossa harjoittelu tapahtuu mahdollisimman realistisessa virtuaaliympäristössä.

Avoimista mutta ei-kontekstuaalisista oppimistilanteista esitetään kuviossa esimerkkinä henkilökohtaiset opiskelusuunnitelmat (hopsit), sen vuoksi, että ne saattavat jäädä todellisuudesta irrallisiksi, mikäli opiskelijoiden valittavana olevat modulit on johdettu perinteisestä oppiaineperustaisesta luokkahuone-opetussuunnitelmasta (kts. esim. Kinnunen \& Mikkonen 1995). Vaikka valinnanvapaus ja joustavuus sisältöjen suhteen lisääntyy, ei kontekstuaalisuus automaattisesti toteudu ellei valittaviin tai räätälöityihin osioihin ole liitetty työelämäyhteyttä tai työssä oppimista (esim. työprojektit, oppisopimuskoulutus). Kuvion avoimessa päässä telemaattisia välineitä voidaan käyttää lisäämässä valinnanvapautta, vuorovaikutusta ja ajasta ja paikasta vapautumista. Tällöin välineitä tulee olla useita vaihtoehtoisia, koska muuten ne enemmänkin rajoittavat kuin avaavat opiskelijan oppimisympäristöä.

Käytännön esimerkki avoimesta ja kontekstu- aalisesta telemaattisia välineitä hyödyntävästä oppimisympäristöstä voisi olla tilanne, jossa opiskelijoilla on mahdollisuus opiskella ja soveltaa omaan elämäntilanteeseensa ja työhönsä läheisesti liittyviä oikeita asioita mahdollisimman joustavasti ja yksilöllisesti, hyödyntäen kaikkia modernin tietoliikenneteknologian tarjoamia mahdollisuuksia.

\section{Lopuksi}

Artikkelissa on pyritty nostamaan esille ja jäsentämään uusista oppimisympäristöistä käytävään keskusteluun liittyvää käsitteellistä problematiikkaa. Avoimista, virtuaalisista jne. oppimisympäristöistä puhuttaessa ei useinkaan määritellä minkälaisia didaktisia ratkaisuja kuvattava kohde käytännössä pitää sisällään. Joskus nämä saattavat olla kaikkea muuta kuin 'avoimia'. Ongelmallista on myös, jos tekniikkaa hyödyntävät koulutusratkaisut nähdään automaattisesti avoimina, joustavina ja oppimista edistävinä. Avoimuutta ei tulisi myöskään nähdä joko-tai tilanteena, vaan useista eri osatekijöistä koostuvana ilmiönä. Avoimuus erilaisissa oppimistilanteissa toteutuu monilla eri tavoin, ja aina ei ole edes didaktisesti järkevää tai mahdollista pyrkiä avoimuuteen ja joustavuuteen. Artikkelissa on esitetty hahmotelma avoimen oppimisympäristön mallista, jonka avulla on mahdollista paikantaa ja arvioida erilaisten oppimistilanteiden osatekijöiden avoimuuden astetta.

Oppimisympäristöjä tulisi rakentaa nykyistä enemmän didaktisesta näkökulmasta, ottaen huomioon aikuisten oppimisen erityispiirteet, erilaiset oppimisen lajit ja oppimisteoreettiset näkökulmat. Oppimisympäristön rakentamisen 
kannalta on varmaankin merkitystä sillä, pyritäänkö opiskelemaan esimerkiksi erilaisia luonnonlakeja selittäviä periaatteita konstruktivismin varaan rakennetun oppimiskäsityksen pohjalta vai vapautumaan omia toimintatapoja rajoittavista asennelukoista kommunikatiivisen oppimisen (Mezirow 1991) avulla. Entä miten opiskella polkupyörällä ajoa virtuaalisesti? Erilaisten oppimisympäristöjen didaktisten ja oppimisteoreettisten periaatteiden jäsentäminen olisikin keskustelun ja kehittämistyön kannalta jatkossa ensiarvoisen tärkeää.

\section{Iäteat}

AHTEENMÄKI-PELKONEN, L. (1994) From self-directedness to interdependence? An analysis of Mezirow's conceptualization of self-directed learning. In: Tösse, S. \& Wahlgren, B. \& Manninen, J. \& Klasson, M. (1994) (eds.) Social Change and Adult Education Research Adult Education Research in Nordic Countries 1992/ 93. Trondheim: Norsk Voksenpedagogisk Institut.

DUFFY, T. \& JONASSEN, D. (1992) Constructivism: new implications for instructional technology. In: T. Duffy \& D. Jonassen (eds.) Constructionism and technology of instruction: a conversation. New Jersey: Lawrence Erlbaum Associates.

INGLIS, A. (1996) Theories of learning in educational development: relocating the paradigmatic divide. Open Learning, vol. 11 no. 2.

JARVIS, P. (1990) The theory of adult education. In: Huey B. Long et al. (Eds.) Advances in research and practice in self-directed learning. Oklahoma: Research Center for Continuing Professional and Higher Education.

JONASSEN, D.H. (1996) (ed.) Handbook of Research on Educational Communications and Technology. New York: Macmillan Library Reference.

KAUPPI, A. (1993) Mistä nousee oppimisen mieli? Kontekstuaalisen oppimiskäsityksen perusteita. Teoksessa: $A i$ kuisen oppimisen undet muodot. Helsinki: Aikuiskasvatuksen tutkimusseura / Kansanvalistusseura.

KAUPPI, A. (1989) Aikuiskoulutuksen sunnittelun kebityslinjoja. Helsinki: VAPK.

KAUPPI, A. (1995) Monimutkaiset yritysympäristöt avoimina oppimisympäristöinä. Helsinki: Opetushallitus.

KEEGAN, D. (1996) Foundations of Distance Education. (3rd ed.) London: Routledge.

KINNUNEN, P. \& MIKKONEN, P. (1995) Tubisten tuloksia - tutkimus benkilökobtaisten oppimissunnnitelmien vaikuttavundesta akateemisessa aikuiskoulutuksessa. Lapin yliopiston täydennyskoulutuskeskuksen julkaisuja no. 43. Rovaniemi: Lapin Yliopisto.

KONTIAINEN, S. \& MANNINEN, J. (1997) Quality of adult learning. Use of conceptual models in describing individual learning processes. In: Social change and adult education research. Adult education research in Nordic Countries 1996. Jyväskylä: Institute for Educational Research.
LEHTINEN, E. (1997) Tietoyhteiskunnan haasteet ja mahdollisuudet oppimiselle. Teoksessa: Lehtinen, E. (toim.) Verkkopedagogiikka. Helsinki: Oy Edita Ab.

LEWIS, R. (1992) What is open learning? In: A. Tait (Ed.) Key issues in open learning. Milton Keynes: Open University Press.

LONKA, K. (1997) Explorations of Constructive Processes in Student Learning. Deparment of Psychology, University of Helsinki. Helsinki: Yliopistopaino.

MANNINEN, J. \& KAUPPI, A. \& KONTIAINEN, A. (1988) Koulutussunnittelun läbtökobtia - analyysi Knowlesin andragogiikasta didaktisena lähestymistapana. Helsingin yliopisto, kasvatustieteen laitos, tutkimuksia 116.

MANNINEN J. (1991) Computer Conference as Learning Environment. Experiences from Computer-mediated Facilitating. In Proceedings: Nordisk konferanse om fjernundervisning, oppläring og dataformidlet kommunikasjon. 19-20 August 1991, Oslo, Norge.

MANNINEN, J. (1992) Tietokonevälitteinen viestintä etäopetuksessa. Teoksessa: Hein \& Larna (toim.) Lähellä, kaukana, yksin, ybdessä - näkökulmia monimuoto-opetukseen. Helsinki: Lahden Tutkimus- ja koulutuskeskus. ss. 119 - 133.

MANNINEN, J. (1996) Kadonneen aarteen metsästäjät? Akateemisille työnhakijoille tarkoitettujen yksilöllisten täydennyskoulutusohjelmien vaikuttavuus. Helsinki: Lahden tutkimus- ja koulutuskeskus.

McISAAC, M.S. \& GUNAWARDENA, C.N. (1996) Distance Education. In Jonassen, D.H. (ed.) Handbook of Research on Educational Communications and Techno$\log$. New York: Macmillan Library Reference USA, 403437.

MERRIAM, S. (1993) Multiculturalism and adult education: questions to guide our research. Journal of Lifelong Learning 2, 57-60.

MEZIROW, J. (1991). Transformative dimensions of adult learning. San Francisco: Jossey-Bass.

PANTZAR, E. \& VÄLIHARJU, T. (1996) Kobti virtuaalisia oppimisympäristöjä. Avoimet oppimisympäristöt aikuisten ammatillisen oppimisen puitteina. Ammatti-instituutti, Julkaisu $1 / 96$.

PAULSEN, M. (1992) The hexagon of cooperative freedom. Deosnews 3, 2.

ROWNTREE, D. (1992) Exploring open and distance learning. London: Kogan Page.

TELLA, S. (1994) Uusi tieto- ja viestintätekniikka avoimen oppimisympäristön kebittäjänä. Osa 1. Helsingin yliopiston opettajakoulutuslaitos. Helsinki: Yliopistopaino.

TENNANT, M. (1988) Psychology and adult learning. London: Routledge.

TERTSUNEN, T. \& VITELI, J. (1997) Digitaaliset matemaattis-luonnontieteelliset oppimisympäristöt. Teoksessa: Entäs nyt, tietoybteiskunta? Interaktiivinen teknologia koulutuksessa konferenssin raportti. Hämeenlinna: Hämeen kesäyliopisto.

WILSON, B. (ed.) (1996) Constructivist Learning Environments: Case Studies in Instructional Design. Englewood Cliffs, NJ: Educational Technology Publications.

Artikkelion saa punut 19.8.1997. Se on hyvä ksytty julka istava ksi 10.11 . 